\title{
QUEEN'S
UNIVERSITY
BELFAST
}

\section{Pitt-Hopkins syndrome}

McAleer, P. (2021). Pitt-Hopkins syndrome. Learning Disability Practice, 24(4), 15-16.

https://doi.org/10.7748/ldp.24.4.15.s6

\author{
Published in: \\ Learning Disability Practice
}

Document Version:

Peer reviewed version

Queen's University Belfast - Research Portal:

Link to publication record in Queen's University Belfast Research Portal

\section{Publisher rights}

Copyright 2021, RCN Publishing (RCNi)

This work is made available online in accordance with the publisher's policies. Please refer to any applicable terms of use of the publisher.

\section{General rights}

Copyright for the publications made accessible via the Queen's University Belfast Research Portal is retained by the author(s) and / or other copyright owners and it is a condition of accessing these publications that users recognise and abide by the legal requirements associated with these rights.

Take down policy

The Research Portal is Queen's institutional repository that provides access to Queen's research output. Every effort has been made to ensure that content in the Research Portal does not infringe any person's rights, or applicable UK laws. If you discover content in the Research Portal that you believe breaches copyright or violates any law, please contact openaccess@qub.ac.uk. 
Pitt Hopkins Syndrome

Pitt Hopkins Syndrome (PTHS) is a rare genetic disease which was first described by Australian physicians, David Pitt and lan Hopkins in 1978. To date, only 500 clinical cases of PTHS have been described worldwide (Sparber et al 2020). Whilst the global prevalence of PTHS is unknown, estimates based on unpublished case data in the United Kingdom and Netherlands range from 1:225,000 to 1:300,000. Severe intellectual disabilities are indicated in $98-100 \%$ of confirmed cases (Zollino et al 2019).

Diagnosis

PTHS affects both sexes and is caused by an abnormal expression of the Transcription Factor 4 (TCF4) gene, leading to deletions or mutations on the $18^{\text {th }}$ chromosome. Global development delay and intellectual disabilities are usually apparent in the first year of life. Diagnosis is made using genetic testing in combination with clinical diagnostic criteria based on physical, developmental and psychosocial phenotypical indicators. Caution is advised when diagnosing PTHS due to phenotypic overlap with neurological disorders such as Angelman Syndrome, Rett Syndrome and Cornelia de Lange Syndrome (Watkins et al 2019, Bonello et al 2017).

Clinical Features

PTHS can lead to a number of dysmorphic physical and skeletal features which include:

- narrow forehead,

- wide nasal bridge

- cupid bow upper lip,

- microcephaly,

- scoliosis.

Individuals with PTHS will frequently present with chronic and severe constipation, breathing anomalies such as intermittent hyperventilation or waking apnoea, hypotonia and delayed gross motor development (Zollini et al 2019). Delayed development of communication skills and impairments in social interactions are common. Repetitive play and stereotypical motor behaviours occur more frequently than others with severe intellectual disabilities. The behavioural phenotype may also include agitation, anxiety, selfinjurious behaviour and Autistic Spectrum Disorder (van Balkom et al 2012). Epileptic seizures occur in $37-50 \%$ of cases with onset between the first year of life and early adulthood (Zollini et al 2019).

Needs Assessment and Treatment

Due to the recency of its discovery, it is not known whether PTHS is a life limiting condition, however given the pervasive complexity of symptoms and comorbid conditions, individuals will likely require considerable support to maintain physical wellbeing. A multidisciplinary needs assessment is recommended (Zollini et al 2019).

Breathing abnormalities result in cyanosis and fainting however they are not associated with lasting neurological damage. Individuals may benefit from a Speech and Language Therapy assessment due to increased risk of respiratory tract infections. Supportive and adaptive communication systems will assist individuals with PTHS to effectively communicate pain and distress (Goodspeed et al 2018). Pain resulting from gastrointestinal disturbances, such as constipation, is linked with anxiety and self-injurious behaviours. Constipation may respond to Positive Behavioural Support, toilet sitting after meals and accurate evaluation using constipation diaries (Zollini et al 2019).

Case Study 
Peter is nineteen years old and lives at home with his parents. He was born full-term without complications during pregnancy or delivery. Diagnosis of PTHS was made at 24 months following genetic testing, indicated by delayed global development and observation of facial features including a flattened mid-face, hypotelorism and a cupid's bow lip. From an early age, Peter has experienced episodic apnoea and cyanosis. Over the last two months Peter has begun having tonic clonic seizures shortly after some apnoeic episodes. Following a neurological assessment, Peter has been diagnosed with epilepsy. His parents now understand his apnoea is caused by anxiety or excitement. Peter was assisted to attend an EEG using a social story and is offered relaxation therapies. The Epilepsy Nurse Specialist has developed an epilepsy management plan for Peter and he also receives an annual health assessment and health action plan.

Further Information

Pitt Hopkins UK https://pitthopkins.org.uk/

References

Bonello, D., Camilleri, F. and Calleja-Agius, J. (2017). Angelman Syndrome: Identification and Management. Neonatal Network, 36(3), pp.142-151.

Goodspeed, K., Newsom, C., Morris, M.A., Powell, C., Evans, P. and Golla, S. (2018). PittHopkins Syndrome: A Review of Current Literature, Clinical Approach, and 23-Patient Case Series. Journal of Child Neurology, [online] 33(3), pp.233-244. Available at: https://pitthopkins.org/wp-content/uploads/2018/05/pitt-hopkins-article-1.pdf.

Sparber, P., Filatova, A., Anisimova, I., Markova, T., Voinova, V., Chuhrova, A., Tabakov, V., Skoblov, V., (2020) 'Various haploinsufficiency mechanisms in Pitt-Hopkins syndrome', European Journal of Medical Genetics, 63(104088), pp. 1-4.

van Balkom, I.D.C., Vuijk, P.J., Franssens, M., Hoek, H.W. and Hennekam, R.C.M. (2012). Development, cognition, and behaviour in Pitt-Hopkins syndrome. Developmental Medicine \& Child Neurology, 54(10), pp.925-931.

Watkins, A., Bissell, S., Moss, J., Oliver, C., Clayton-Smith, J., Haye, L., Heald, M. and Welham, A. (2019). Behavioural and psychological characteristics in Pitt-Hopkins syndrome: a comparison with Angelman and Cornelia de Lange syndromes. Journal of Neurodevelopmental Disorders, 11(1).

Zollino, M., Zweier, C., Van Balkom, I.D., Sweetser, D.A., Alaimo, J., Bijlsma, E.K., Cody, J., Elsea, S.H., Giurgea, I., Macchiaiolo, M., Smigiel, R., Thibert, R.L., Benoist, I., Clayton-Smith, J., De Winter, C.F., Deckers, S., Gandhi, A., Huisman, S., Kempink, D., Kruisinga, F., Lamacchia, V., Marangi, G., Menke, L., Mulder, P., Nordgren, A., Renieri, A., Routledge, S., Saunders, C.J., Stembalska, A., Van Balkom, H., Whalen, S. and Hennekam, R.C. (2019). Diagnosis and management in Pitt-Hopkins syndrome: First international consensus statement. Clinical Genetics, 95(4), pp.462-478. 
